\title{
Development of Oriented Student Activity Sheets Problem-Based Learning Approaches Assisted by GeoGebra Software to Improve Metacognition Ability of Private Vocational High School PAB 12 Saentis
}

\author{
Rusmini $^{1} \quad$ Edy Surya $^{2}$ \\ 1.Lecturer, Information Systems, Potensi Utama University \\ K.L. Yos Sudarso K.m 6,5 No. 3-A Tanjung Mulia -Medan, North Sumatera, Indonesia \\ 2.Lecturer, State Medan University, Willem Iskandar Pasar V Street, Medan,North Sumatera, Indonesia
}

\begin{abstract}
This study aims to describe student activity sheets developed in oriented learning problem-based learning approaches which include: 1) validity, 2) practicality 3) effectiveness 4) improvement of students' metacognitive abilities using student activity sheets in software-oriented problem-based learning approaches assisted by software GeoGebra developed, 5) identified the level of students 'metacognitive abilities in solving problems based on the results of students' metacognitive abilities tests. This research is research and development, the product produced is a student activity sheet oriented to a problem-based learning approach developed using a 4-D development model. The subject of this study was the grade X student of Private Vocational High School PAB 12 Saentis. From the results of the second trial obtained the activity sheet students meet the criteria: 1) valid, good 2) practical, in terms of: a) validator assessment, b) student response interviews, c) teacher response interviews, and d) implementation of student activity sheets 3 ) effective, in terms of a) completeness of classical learning outcomes, b) student activities, c) student positive responses, 4) there is an increase in metacognitive abilities of students using student activity sheets developed, 5) the level of student metacognition in solving problems only meets the level of strategic ability use, aware use, and tacit use.
\end{abstract}

Keywords: Floating Student Activity Sheet, Problem-based Learning, 4-D Model, Metacognition Ability

DOI: $10.7176 / \mathrm{JEP} / 10-9-19$

Publication date:March $31^{\text {st }} 2019$

\section{Introduction}

Metacognition is defined by some experts as thinking about thinking, some other experts define knowing about knowing. The ability of self- reflection from a process of thinking or cognitive processes that take place in an individual and which plays an important role in human consciousness, it is an indication that metacognition is included in one's thinking. According to Desoete, 2000; Fogarty, 1994 (Laurens ,2010) the notion of metacognition is almost the same an understanding reflection on what individuals think. Conceptually metacognition is defined as a person's knowledge of the process of thinking itself the ability to monitor and direct the processes and results of their own thinking and evaluate the thinking process and the results of their own thinking. Furthermore, it is said that the ability of metacognition is believed to be a high-level ability needed for knowledge management where students are required to set their own learning goals and determine appropriate learning strategies to achieve these goals (Fujiank dkk (2016).

Student metacognition really needs to be improved because metacognition is something of the inner strength of students about the process of realizing the ability and regulating students' thinking in solving problems. Metacognition essentially emphasizes the awareness of thinking about the thought process itself. According to O’Neil \& Brown in 1977 (Tayeb \& Putri, 2017) stated metacognition as a processability someone thinks in order to develop strategies to solve problems. The concept of metacognition is the idea of thinking about thoughts in oneself. As for those included in the concept of metacognition is awareness about: 1) what is known to someone, (awareness and deep understanding of the processes and products a person has. (2) what one can do about one's own cognitive abilities (one's ability to monitor or regulating its cognitive activity during problem solving, according to Flavell, Wellman in 1985 (Tayeb \&Putri, 2017) that the importance of metacognition was introduced in the world of education because metacognition as a form of cognitive ability, or the ability of two-level thinking processes or more involving control over cognitive activity, Flavell defines metacognition, Metacognition as an ability to understand and monitor one's own thoughts and assumptions and implication of one's activities Metacognition as the ability to understand one's own thinking and the conjecture and implications of one's activities. above, it can be emphasized that metacognition is an ability to understand thinking activities, so that the metacognition process of each person will differ according to his ability, and it is very necessary to improve in classroom learning, especially mathematics learning, because with increased metacognitive abilities students will automatically contribute to the ability mathematical problem solving of students.

The ability of metacognition is very important in problem- solving, according to research conducted by Lester, 
Garofalo, and Kroll in 1989 ( Murti \& Hastjarjo, 2015) in class VII students that there was a role for metacognition in solving mathematical problems. Therefore it needs to be developed or improved. According to Larkin 2006 (Murti, 2017) that metacognition develops in individuals as they age and are influenced by practice. Interaction with each other can provide stimuli needed by individuals to become more aware of their cognitive processes. Therefore, in order an individual or student metacognition to develop well or increase it is necessary to do exercises that provide a stimulus during classroom learning. The stimulus was given to be more maximal, the stimulus must be designed in such a way. The stimulus can be in the form of learning strategies, learning approaches or learning models and teaching materials that are used and developed according to the material being taught. Student activity sheets that are developed as well as learning approaches that are in accordance with the material, as well as the character of the students are solutions to provide stimuli to students to support the development of metacognition or increase the metacognition of students when solving mathematical problems.

The student activity sheet (LAS) is a learning resource needed and is a stimulus for students in the learning process. A good student activity sheet will make students feel happy to learn and make the learning experience. In addition, LAS is made according to the conditions, needs, and characteristics of students. LAS does not only contain questions and discussion and practice questions but there is a process of construct understanding to problem-solving, and permanent understanding. LAS like this can help students to build a good understanding and guide students to discover the concepts of material themselves. If a student understands a material, chances are that he will continue to remember it and also can apply it when solving problems presented.

Besides the student activity sheet, it is necessary to use technology to teach mathematics. This technology serves to make students more interested in the material being studied and students will feel happy with the learning process they are going through. The use of technology in mathematics learning has various kinds such as audio, visual or audiovisual media. One medium that can be a stimulus for students and an attraction for students is Geogebra media. Geogebra is a medium of mathematics learning based on dynamic geometry computing systems. This dynamic computational nature encourages attraction for students to know mathematical concepts visually according to Rahmadi (Ardina, 2016) . Based on the results of the study that the development of student activity sheets assisted by GeoGebra software helped students understand the material limits of algebraic functions and met valid criteria (Ardina, 2016)

Geogebra is a mathematical software that is packaged in one package that is easy to use in learning at all levels of education. Geogebra software combines geometry, algebra, calculus , and statistics. Geogebra is an open source software that can be accessed by anyone at www. geogebra.org (Howenwaiter \& Lavicza ,2007). With GeoGebra software, it is expected to be able to improve students' metacognition process, which in turn will train students in the process of solving mathematical problems independently of quadratic function learning, especially class X of of Private Vocational High School PAB 12 Saentis.. Here the students at the time of learning presented problems that were packaged on the student activity sheet, which were developed in accordance with the quadratic function material and at the time of problem solving students were invited to train their metacognition process, which is a process where students know what they really know to solve their problems and a process of metacognitive skills students is how students process problem solving solutions given on student activity sheets that have been packaged according to the character of students and the conditions of students during learning, where it is expected that students' metacognition process will increase.

Based on the above description of the importance of developing student activity sheets that can improve student metacognition and student learning atmosphere that are fun and not boring in quadratic function material, in this study, researchers developed student activity sheets on quadratic function material. This research was entitled "Development of Student Activity Sheets oriented to problem-based learning approach assisted by geogebra software to improve the metacognitive abilities of class X Private Vocational High Schoo1 PAB 12 Saentis. According to Akker and Nieeven (Tetty \& Sinaga, 2017) that a good Student Activity Sheet must be fulfilled its validity, effectiveness and classification, so the objectives of this study refer to that which are: 1) developing student activity sheets oriented to assisted problem-based learning approaches geogebra software for learning quadratic function material in class X SMK students, 2) knowing the quality of the activity sheet of students oriented problem-based learning approach assisted by geogebra software students of class X SMK in terms of: a) validity, b) practicality c) effectiveness. Furthermore, 3) to find out the improvement of students' metacognitive abilities using student activity sheets on learning oriented problem-based learning approaches assisted by geogebra software developed, 4) Identify the level of students' metacognitive abilities in solving problems based on the results of students' metacognitive ability tests. Quadratic function learning with the help of geogebra software is expected to provide color, innovation, creativity in the students' metacognition process in learning at school. Because with this teaching material students will be able to directly explore the process of metacognition on quadratic function concepts so that they simultaneously understand and design the problem solving process independently, which in turn will train the process of students' metacognitive abilities to the fullest. 


\section{Research Methods}

This type of research is a research development of student activity sheets using a 4-D model developed by Thiagarajan, Semmel and Semmel 1974 (Yunita dkk, 2017). This development model generally consists of 4 stages, namely: (1) define stage , aims to determine and define learning needs; (2) the design stage (design), namely the design of the Student activity sheet prototype; (3) the stage of development (development), aims to produce a Student Activity Sheet; (4) the diseeminate stage (spread), which is the stage of using student activity sheets developed (Trianto, 2009). In detail the data and information taken from the assessment instruments include: 1) student response questionnaire sheets, 2) observation sheet for student activities, 3) metacognition interview sheets, 4) student metacognition ability test sheets, 5) assessment sheets (LAS validation), 6) Test sheet for diagnosing students' metacognitive abilities. Data from material experts, media experts and student responses and students' metacognitive abilities were then analyzed.

\section{Results and Discussion}

This study produced a product of student activity sheets which was supplemented with a media tutorial for solving mathematical problems assisted by geogebra software with quadratic function material which aimed to improve students' metacognitive abilities. The sub section of the student activity sheet developed is as follows:

Problem:

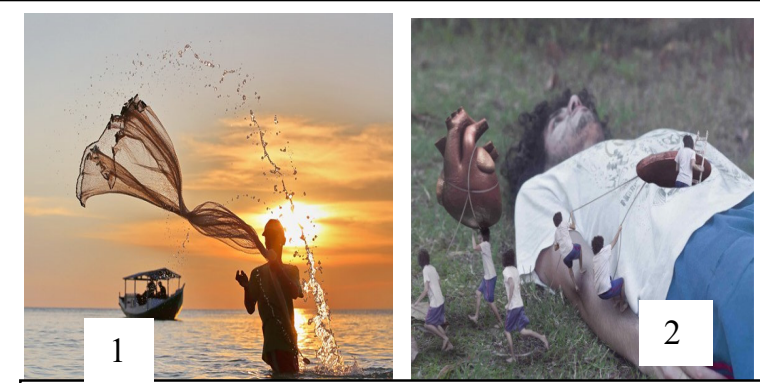

Source:www.geoogle.com (1) direct shooting, 2) editing
A photographer can produce good images through two stages, namely the shooting stage and the editing stage. The cost required at the shooting stage is (B1) is Rp.600.00 a picture, follows the function $\mathrm{B} 1(\mathrm{~g})=600 \mathrm{~g}+2,000$ and the cost in the editing stage (B1) is Rp100,00 a picture, following the function B2 $(\mathrm{g})=100 \mathrm{~g}+600$, with $\mathrm{g}$ is a lot of images produced. According to predictions the total cost of shooting will be cheaper than at the editing stage.

a. What is the total cost needed to produce 10 images of good quality?

b. Determine the difference between the costs at the shooting stage and the costs at the editing stage for the 5 images?

In solving problems include:

Figure 1 Problem (1) direct shooting, 2) editing

3.1. Metacognition questions such as:

a. What initial knowledge will help you in solving the above questions?

b. What did you first do after reading the question?

c. How long will you complete this problem completely? why is that?

d. What do you need to do if after reading the question, but do not understand the problem given?

e. How do you solve the problem above?

f. Why are you sure that the answer process you made is correct?

3.2. Presenting a problem -solving tutorial that is similar to the concept in LAS material, so students are led to solving their own problems by referring to the knowledge in the GeoGebra software tutorial such as:
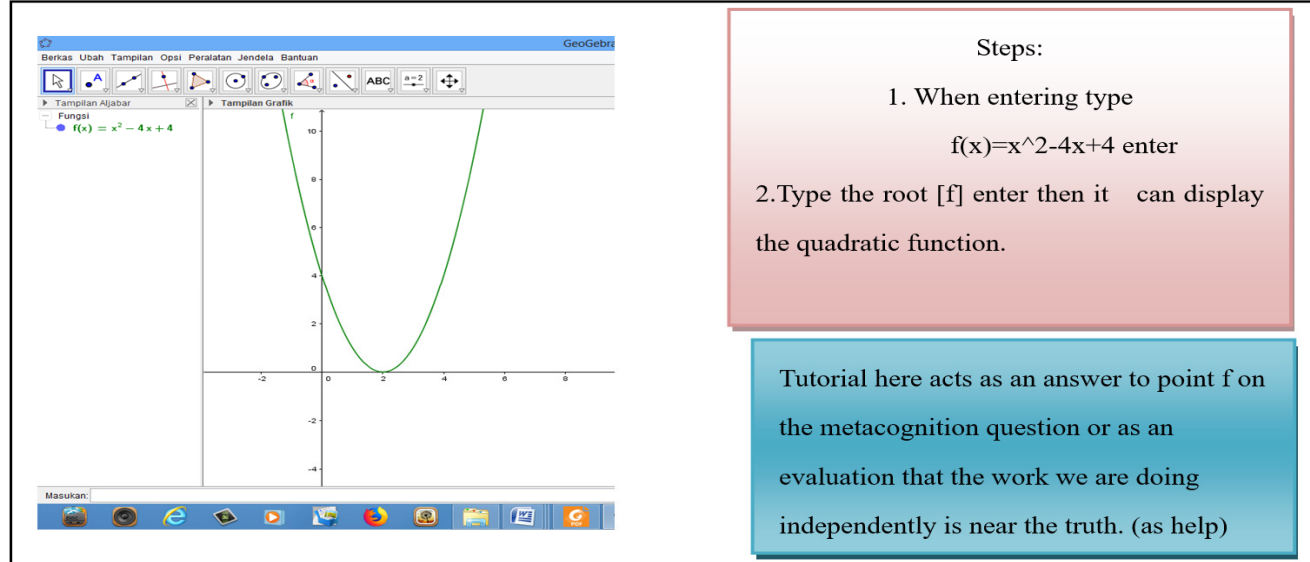

Figure 2 Problem Solving With Assisted by GeoGebra 
Based on the results of the research data, the following results are obtained: students are very happy to use student activity sheet instruments that are developed based on problem-based approaches assisted by GeoGebra software on quadratic function material that has been validated by material experts and media experts. The data of the research include: 1) student response questionnaire, positive student response, 2) student activity observation sheet, namely: active students in learning and students are directed to independent learning in accordance with the application of self-regulated learning or SRL (Amir \& Risnawati, 2016) one of the supporting factors is involving students actively in learning, namely by operating computers in a laboratory room so that they are created conducive and happy because students actively carry out their tasks in solving problems, 3) metacognitive interview sheets that students feel happy and students' self-confidence increases with the evaluation of their work in solving problems using geogebra software independently becomes a motivation in solving problems in accordance with Rusmini \& Surya E (2017) research, which is an indicator of self-confidence including trying to develop one's abilities and do the exercises to achieve success, have high motivation, thus increasing their selfmetacognitive thinking process to find out the things they will use in the process of solving the mathematical problem, 4) test sheets for students' metacognition abilities, namely the increase in results after being done calculation of data obtained before geogebra software assisted learning and after learning with the help of geogebra software, because geogebra software assisted learning is a strategy to motivate student learning by regulating the situation or atmosphere of a conducive learning. This created condition becomes reinforcement for students (Sagala, 2014). Furthermore, the pre-test and post-test data are calculated based on Gain Index, 5) assessment sheet (LAS validation and lesson plan), which is based on the validation assessment sheet that is declared valid (average validity $=4.52$ ) and effective

For the pre-test results obtained the average metacognition result was 50.02, the presentation of completeness was $6.67 \%$ ( 2 of the students who understood the question of metacognition). From the post-test results (Average trial I and trial II) for students obtained an average score of 72.89. In the second trial, the level of students' metacognition ability was better than that of the trial I because students already had a learning experience from the trial I, this was in accordance with the opinion of Gestalt (Sanjaya, 2017) learning is the process of developing insight. Insight is influenced or depends on relevant past experience. Students in classical completeness averaged $86.67 \%$ (26 students from 30 students), meaning learning using student activity sheets oriented to problem-based learning approaches assisted by GeoGebra software has contributed to improving students' mathematical metacognition skills.

The results of research (Hohenwarter dkk, 2004, 2008) that GeoGebra software assisted learning is very helpful in visualizing abstract mathematical concepts and helping to evaluate problem -solving that students are working on student activity sheets. The same thing with the research of Supriadi et al (2014) that there were differences in the results of students 'mathematical abilities in learning assisted by GeoGebra software with learning without the help of GeoGebra software where students' motivation, creativity, and mathematical abilities were higher with the help of GeoGebra software. Furthermore, according to Khotimah's research (2018), the ability of mathematical literacy with a GeoGebra-assisted metacognitive approach has improved better than conventional learning. In line with Isaiah's (2015) study that student performance in mathematics, regardless of gender, can be greatly improved through the incorporation of GeoGebra software into instruction in mathematics classes.

\section{Conclusion}

Based on the results and discussion in this study, it can be concluded:

1. Development of student activity sheets using a modified 4-D model is valid, namely student activity sheet includes: student activity sheet 1, activity sheet 2 activity sheets 3 .

2. Test of student metacognition ability (TKM) that can be seen in the effectiveness of learning-oriented problem-based learning approaches assisted by GeoGebra software fulfills effective criteria indicated by fulfilled completeness, active tolerance limits of students, student responses to student activity sheets and positive learning skills from skills student metacognition.

3. Processes the answers of students from trial II are better than trial I

4. With the development of GeoGebra software-assisted student activity sheets, it also contributes to the development of ICT, namely GeoGebra software in mathematics learning, so that students who previously did not know that mathematics learning had been boring in principle, apparently there was software that could ease problem -solving mathematics so students feel happy in learning.

5. But there are obstacles that we have to pay attention to, namely teachers will be busier and must be extra in guiding students in the class, at least during learning laboratory space with adequate computer facilities with the number of students and GeoGebra software has been installed.

6. At the time of learning, a minimum of 2 supervisors should be sought if only one person is trying to make students smarter as learning with peers.

7. Requires a long time. 


\section{References}

Amir \& Risnawati. (2016). Psikologi Pembelajaran Matematika. Yogyakarta: Aswaja Pressindo.

Ardina (2010). Lembar Kerja Siswa Berbantuan Geogebra Sebagai Upaya Membantu Pemahaman Siswa Materi Limit Fungsi Aljabar. Jurnal Math Education Nusantara. Volume 02 Nomor 01, Mei 2016.

Fujiank, et al. (2016). Kemampuan Metakognisi Mahasiswa Program Studi Pemdidikan Biologi FKIP Universitas Mataram, Jurnal Pendidikan Teori, Penelitian, dan Pengembangan. Volume:1 Nomor: 10 Bulan Oktober Tahun 2016 Halaman: 2016-2022

Howenwaiter \& Lavicza (2007). Introduzione a GeoGebra. Creative Commons Attribution-Noncommercial-Share Alike. Versione italiana.

Howenwaiter dkk. (2004). Combination of dynamic geometry, algebra and calculus in the software system GeoGebra. University of Salzburg, Departement of Mathematics and Computer Science Education, HellbrunnerstraBe 34, A-5020 Salzburg, Austria; e-mail: hohenwarter@sbg.ac.at;web:http://www.geogebra.at

Howenwaiter, et al. (2008). Teaching and Learning Calculus with Free Dynamics Mathematics Software GeoGebra. Research and development in the teaching and learning of calculus ICME 11, Monterrey, Mexico 2008.

Isaiah. A.A. (2015). Effect of GeoGebra Package on Learning Outcomes of Mathematics (Secondary School) Students in Ogbomoso North Local Government Area of Oyo State. Departement of Science and Technology Education, Faculty of Education, Obafemi Awolowo University, Ile-Ife Nigeria. Akade3@gmail.com

Khotimah (2018). Meningkatkan Kemampuan Literasi Matematis Dengan Pendekatan Metakognitive Guidance Berbantuan Geogebra. Jurnal Pendidikan Matematika, Vol.01, No.01 Mei 2018

Laurens (2010) Penjenjangan Metakognisi Siswa yang Valid dan Reliabilitas, Jurnal Pendidikan Dan Pembelajaran, Volume 17, Nomor 2, Oktober 2010.

Murti \& Hastjarjo (2015). Permainan Imajenatif Berdasarkan Metakognisi Dalam Belajar Matematika, Gadjah Mada Journal Of Psychology, Volume. 1, No. 1, Januari 2015: 1-12 ISSN: 2407-7798.

Murti (2011). Metakognisi Dan Theory Of Mind (ToM), Jurnal Psikologi Pitutur. Volume 1, No. 2 tahun 2011.

Rusmini \& Surya E (2017). The Effect of Contextual Learning Approach to Mathematical Connection Ability and Student Self-Confidence Grade VIII SMP Negeri 8 Medan. International Journal of Science: Basic and Applied Reseach (IJSBAR) (2017). Volume 35 No. 2, pp 249-262.

Syaiful, S (2014). Konsep dan Makna Pembelajaran. Bandung: Alfabeta.

Sanjaya, W. (2013). Strategi Pembelajaran Berorientasi Standar proses Pendidikan. Jakarta: Kencana.

Supriadi, et al. (2014). Developing High - Order Mathematical Thinking Competency On High School Student' Through GeoGebra-Assisted Blended Learning, Journal Mathematical Theory And Modeling. ISSN 22245804(Paper) ISSN 2225-0522 (Online), Vol.4, No. 6, 2014

Trianto (2009). Trianto (2010). Mendesain Model Pembelajaran Inovatif Progresif, Konsep, Landasan dan Implementasinya pada Kurikulum Tingkat Satuan Pendidikan (KTSP). Jakarta: Kencana Prenada Media Group.

Tayeb \& Putri (2017). Kemampuan Metakognisi Untuk Meningkatkan Ketrampilan Pemecahan Masalah Matematika Siswa Kelas VIII B MTS Madani Alauddin Paopao Kabupaten Gowa. Jurnal Matematika Dan Pembelajaran (MaPan.) Vol. 5 No. 1, Juni 2017.

Tetty K, and Sinaga B. (2017). Development of Student Worksheet Geometry Based Metakognitive Strategy Through Creative Thinking Ability. IQSR Journal of Research \& Method in Education (IQSR-JRME). eISSN: 2320-7388,p-ISSN 2320-737X Volume 7, Issu 4 Ver. IV (Jul-Aug 2017), pp 10-18.

Yunita. S, et al. (2017). Development Of Mathematics Based Learning Realistics Mathematics For Improving Metacognition Skills And Students Creative Thinking. Journal Advances in Social Science, Education And Humanities Research, Volume 104, 348-350. 